\title{
Massive beaching record along the sandy coast of Catania (E- Sicily) of the rare "mole crab" Albunea carabus (Linnaeus, 1758) (Decapoda Anomura Hippoidea)
}

\author{
Danilo Scuderi"*, Alberto Villari² \& Massimiliano Angelico' \\ ${ }^{1}$ I.I.S.S. “E. Majorana”, Via L. Capuana 36, 95048 Scordia, Catania, Italy; e-mail: massimiliano.angelico@gmail.com \\ ${ }^{2}$ Via Villa Contino 30, 98124 Messina, Italy; e-mail: villaria@tiscali.it \\ *Corresponding author, e-mail: danscu@tin.it
}

\begin{abstract}
After a winter storm, with sirocco wind, hundreds of specimens of the "mole crab" Albunea carabus (Linnaeus, 1758) (Decapoda Anomura Hippoidea) were beached along the sandy coast of "Playa" Catania (E-Sicily). Even though this species was previously recorded in some scattered localities of the Mediterranean, among which a couple were found in Sicily, the present record appears relevant on account of the massive finding of specimens, which is a quite rare event according to literature data. Considerations on the reasons of this wide beaching complete the present note.
\end{abstract}

KEY WORDS

Mole crab; Albunea carabus; massive beached; river estuary; Catania, Mediterranean Sea.

Received 10.07.2018; accepted 12.09.2018; published online 20.12.2019

Proceedings of the 4th International Congress on Biodiversity "Man, Natural Habitats and Euro-Mediterranean Biodiversity", November 17th-19th, 2017 - Malta

\section{INTRODUCTION}

Amongst Crustacea, Decapoda, which include crayfish, crabs, lobsters, prawns, and shrimp are a highly diverse group since they are adapted to many different marine, freshwater and terrestrial environments. The superfamily Hippidea, commonly known as mole crabs, are Decapoda which includes three families. In the family Albuneidae the genus Albunea Weber, 1795 comprises 22 species (Boyko, 2002), of which Albunea carabus (Linnaeus, 1758) is present in the Mediterranean, from which it was described for the first time. In fact, the first description of $A$. carabus was performed by Linnaeus (1758) as Cancer carabus on specimens from Algiers. Some confusions suddenly happened on the morphological character of the rostrum when Linnaeus described it as formed by "two parallel and movable teeth", but Miers (1878) stated that he was describing the ocular peduncles. We have no type materials of this species and, according to Boyko (2002), no neotype designation is needed since this is the only albuneid present in east Atlantic and the Mediterranean. A complete diagnosis of this species is found in Boyko (2002), who cited it as the main representative species of the "carabus-group" of Albunea, which also comprises two other extant species, $A$. danai Boyko, 1999 and A. bulla Boyko, 2002, and two Miocenic species, A. asymmetrica (Muller, 1979) and A. turritellacola (Fraaije, van Bakel et Jagt, 2008).

Albunea carabus is widespread along the Eastern Atlantic coasts, in Western African regions, 
from Benin to Ivory Coast, Cape Verde Islands included, and in Portugal, Algarve coast and Madeira Islands. In the Mediterranean it is scattered from eastern (Katagan \& Cem, 2003) to western regions (see Pereira et al., 2008 for a comprehensive list of record's localities). Everywhere it is considered very rare, but, according to Boyko (2002), it could be more common on its favorite substrates, which are low sandy bottoms subjected to high hydrodynamism, where it borrows often in proximity of estuaries (Giacobbe \& Spanò, 1996; Spanò et al., 1999; Boyko, 2002; Pereira et al., 2008).

Our material was washed ashore quite abundantly in E-Sicily, in an area north to Simeto, the longest river in the island, and near another minor creek. This finding offered us the possibility to document a massive beaching of this species in the Mediterranean and to create a parallelism with preceding data for the Atlantic Ocean.

\section{MATERIAL AND METHODS}

After a storm in February 2017, approximately two hundreds of specimens were found along a limited stretch of the southern and sandy beach of Catania ("Playa") which is extended up to $18 \mathrm{~km}$ in its whole extension. The inspected area (Fig. 1) is comprised between the southern jetty of the harbor ("Sciara Biscari" zone), where the small creek Acquicella flows into the sea, and $500 \mathrm{~m}$ south at the first free entrance to the beach from the main street. At the moment of the finding a slight wind of Sirocco was present and specimens were accumulated by the low waves along the sandy beach, where marine birds, seagulls and egrets, and stray dogs fed upon them. Only 40 entire specimens were collected (Figs. 2-8), 15 females and 25 males, ranging from $21.2 \mathrm{~mm}$ (male) to $40.2 \mathrm{~mm}$ (female); they were preserved in ethanol.

In addition to the mole crabs, other species of crabs were found, among which the Brachiurids Portumnus latipes (Pennant, 1777), Portunus hastatus (Linnaeus, 1767) and Portunus segnis (Forskål, 1775). A further note should be added on the terrestrial and freshwater material beached together with the "mole crabs". Numerous undetermined freshwater fishes, probably decomposed specimens of Tinca tinca (Linnaeus, 1758), frogs as Pelophylax esculentus (Linnaeus, 1758), lizards as Chalcides ocellatus (Forsskål, 1775), Podarcis siculus Rafinesque, 1810 and Lacerta bilineata Daudin, 1802, snakes as Natrix natrix Linnaeus, 1758) and mammals as Rattus norvegicus Berkenhout, 1769, were contemporaneously found among the very large amounts of residuals of the river cane Phragmites australis (Cav.) Trin. ex Steud., here often beached by the winter storms.

\section{RESULTS}

Albunea carabus (Figs. 3, 4) can be distinguished by the triangular ocular plates (Fig. 5), almost squared in A. bulla, and for the subquadrate ventral margin of the heel of the pereopod $I I$ dactylus (Fig. 6), rounded in the sister species $A$. danai. Females are characterized by a larger and more rounded in shape last segment of the telson (Fig. 7), instead of almost triangulate in males (Fig. 8). Though it appears to be a well distributed species, along the Mediterranean coasts $A$. carabus seem widely distributed, from Eastern to Western regions, but inside restricted environments and with very scarce materials collected (few specimens for each locality). Only the record of Piguet (1955) is known to report a massive beaching of this species for Algerian sandy coast in the same conditions. So, the present finding assumes a particular significance when compared to the others. First of all because our data confirm the environmental preferences known in literature for this almost elusive species: the sandy bottom (SFBC according to Pérès \& Picard, 1964), almost brackish water and the high hydrodynamism. Moreover, the finding of numerous terrestrial and freshwater species of animals and plants suggests that a sudden river overflow occurred, which surprised all these organisms, killed them, producing in the marine ecosystems an exceptional wave of freshwater along the Simeto's surroundings, which caused the massive death of the mole crabs. This explains the large number of specimens collected in the same beach at the same time. Our data confirm therefore this remarkable event, only occasionally reported in literature: the freshwater runoff, in fact, is suggested by Piguet (1955) as possible cause of mortality of a large number of specimens in Algiers. 


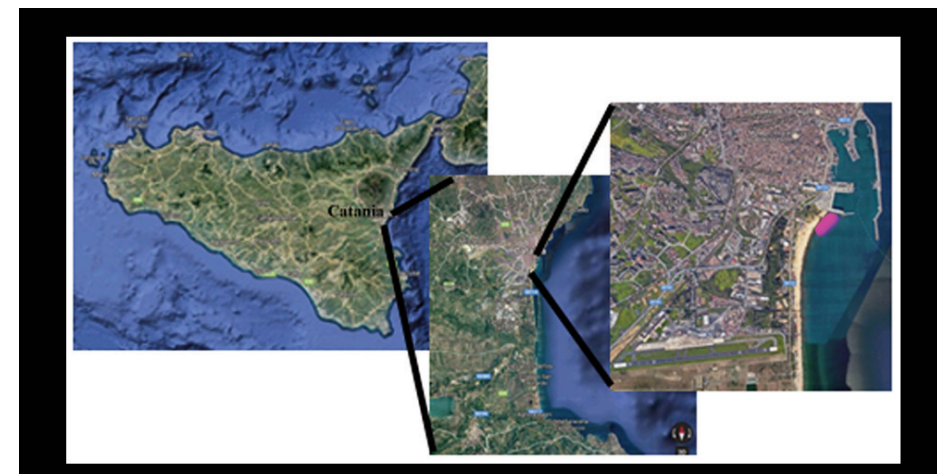

1

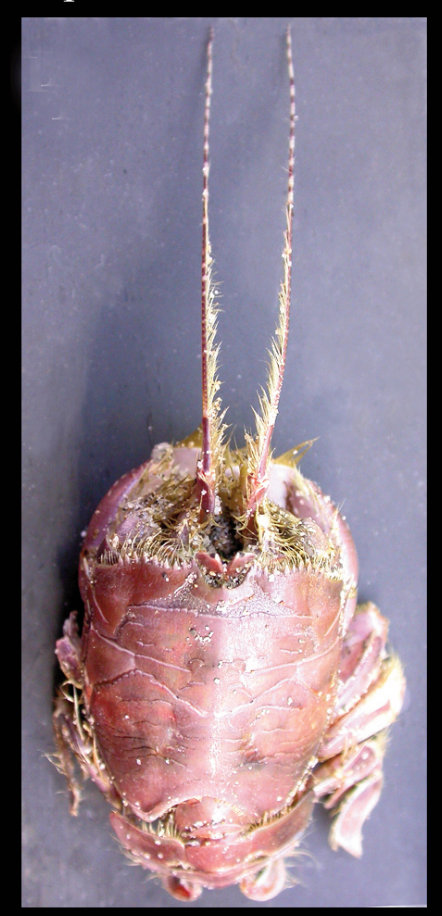

3

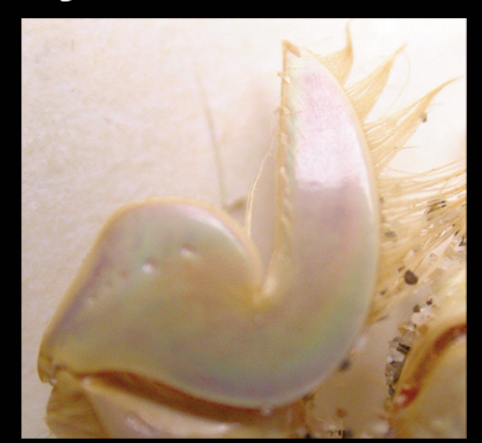

6

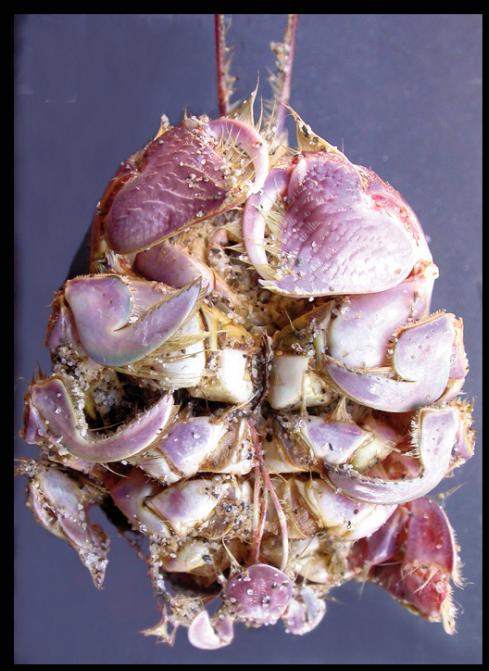

4

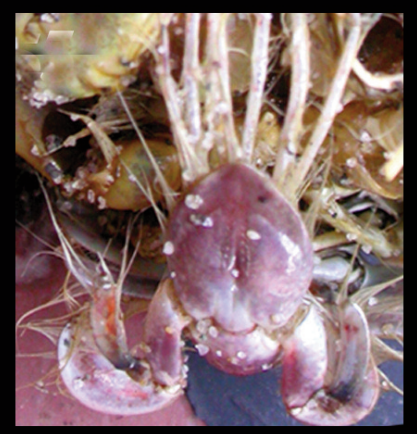

7

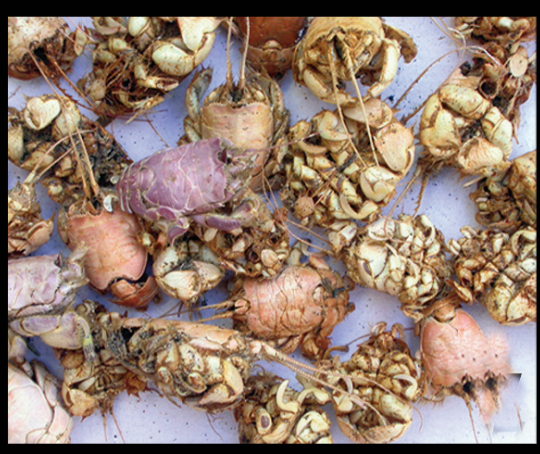

2

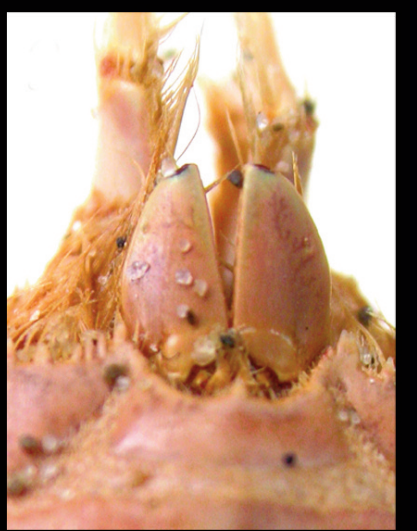

5

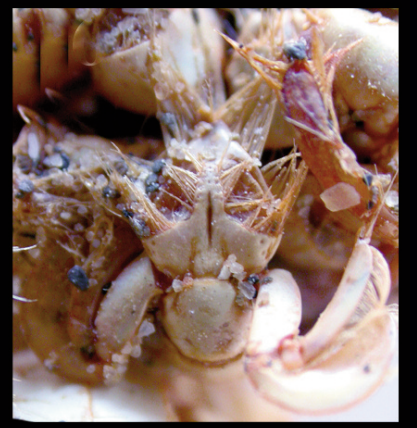

8

Figure 1. Map of the E-Sicily (Italy) with details of the harbor of Catania: pink colored area represents the stretch of the sandy beach where the collected material was found. Figures 2-8. Albunea carabus from Catania "Playa", E-Sicily. Fig. 2: Albunea carabus from Catania "Playa". Fig. 3: whole specimen (female) in dorsal view, h 39.4 mm. Fig. 4: the same specimen in ventral view. Fig. 5: detail of the ocular plates. Fig. 6: detail of the ventral margin of the heel of the pereopod II dactylus. Fig. 7: detail of the female telson. Fig. 8: detail of the male telson. 


\section{ACKNOWLEDGMENTS}

We are grateful to prof. Carlo Froglia (CNRIRBIM, Ancona, Italy) for interesting suggestions and literature assistance.

\section{REFERENCES}

Boyko C.B., 2002. A worldwide revision of the recent and fossil sand crabs of the Albuneidae Stimpson and Blepharipodidae, new family (Crustacea: Decapoda: Anomura: Hippoidea). Bulletin of the American Museum of Natural History: 272: 1-396. http://dx. doi.org/10.1206/0003-0090(2002)272\%3C0001: AWROTR\%3E2.0.CO;2

Giacobbe S. \& Spanò N., 1996. New records of Albunea carabus (L., 1758) (Decapoda, Anomura) in the Mediterranean Sea. Crustaceana, 69: 719-726.

Katagan T. \& Cem C., 2003. A New Record of Albunea carabus (L., 1758) (Decapoda, Anomura, Hippidea) from the Eastern Mediterranean Coast of Turkey. Crustaceana, 76: 637-639.

Miers E.J., 1878. Revision of the Hippidea. Journal of the Linnean Society, Zoology, 14: 312-336.

Pereira A.M., Rufino M.M. \& Gaspar M.B., 2008. First record of Albunea carabus (Decapoda, Anomura, Hippidea) from the Algarve coast, South Portugal. Marine Biology Research, 4: 236-238.

Pérès J.M. \& Picard J., 1964. Noveau manuel de bionomie bentique de la Mer Méditerranée. Recueil des Travaux de la Station marine d'Endoume, 31: 5-137.

Piguet P., 1955. Des échantillons d'un petit crustace decapode anomoure Albunea carabus L. Bulletin de la Société d'Histoire Naturelle de l'Afrique Nord, 46: 14. Spanò N., Rinelli P. \& Ragonese S., 1999. The first find of Albunea carabus (Decapoda: Anomura) on the southern Sicilian coasts (Strait of Sicily, Mediterranean Sea). In: Schramand F.R. \& von Vaupel Klein J.C. (Eds.), Crustaceans and the biodiversity crisis: Proceedings of the Fourth International Crustacean Congress, Amsterdam, the Netherlands, July 20-24, 1998: 617-621. Brill, Leiden. 